\title{
Chronicle of the First China Animal Law Forum - Beijing, July 2019
}

\author{
Bo Li \\ PhD Candidate, Nanjing Normal University, Law School, China
}

Received: July 2019

Accepted: July 2019

Recommended citation. LI, B. Chronicle of the First China Animal Law Forum - Beijing, July 2019, dA. Derecho Animal (Forum of Animal Law Studies) 10/3 (2019) - DOI https://doi.org/10.5565/rev/da.448

\begin{abstract}
On July 11 and 12, 2019 the First China Animal Law Forum was held in Beijing, which was co-hosted by the Capital Animal Welfare Association and the Vshine Animal Protection Association. Over 130 people from mainland China, Hong Kong, USA and Africa took part in the forum, including professionals, lawyers, government, NGO, animal protection volunteers and others. The main topic was how to use laws creatively to protect animals.
\end{abstract}

Keywords: China; Animal Law; Animal Protection.

Resumen - Crónica del Primer Foro de Derecho Animal en China. Beijing - Julio 2019

Entre los días 11 y 12 de julio de 2019 se llevó a cabo el primer Foro de Derecho Animal en China, el que fue co-organizado por la Capital Welfare Association y la Vshine Animal Protection Asociation. Más de 130 personas provenientes de la gran China, Hong Kong, Estados Unidos y África participaron en el Foro, entre los cuales se incluyeron profesionales, abogados, representantes gubernamentales, ONG y activistas, entre otros. El tema principal fue cómo utilizar las leyes, creativamente, en la protección animal.

Palabras clave: China; Derecho Animal; Protección Animal.

The First China ${ }^{1}$ Animal Law Forum was successfully held in Beijing on July 11 and 12, 2019. More than 130 legal experts, scholars and animal protection volunteers from 37 cities of China and abroad participated in the forum.

There is currently no anti-abuse animal law in China. It is not rational to be just waiting around for a law to come to prevent cruelty for animals. How to use existing laws to protect animals is a matter of great concern to the Chinese animal protection groups. Accordingly, the Capital Animal Welfare Association and the Vshine Animal Protection Association co-hosted this forum, focusing on using existing laws creatively to protect animals.

Public interest litigation can be used to protect animals in China. Associate Professor Amanda Whitfort from the Law Faculty of Hong Kong University, and Professor Hairen He from the Institute of Law of the Chinese Academy of Social Sciences, China, respectively delivered speeches on this topic. In the jurisdiction of China, public interest litigation was incorporated into the Civil Litigation in 2012 and Administrative Litigation in 2017. Furthermore, Supreme People's Court Supreme People's Procuratorate Interpretation of Several Issues Concerning the Applicable Law of Prosecuting Public Interest Litigation

${ }^{1}$ China in this chronicle is used in reference to mainland China. 
was effective from March 2, 2018. If social public interest was damaged, the statutory authority and other relevant organizations in some specific situations can file a lawsuit to stop illegal infringement and protect captive wild animals, farmed animals, laboratory animals, and animals in transport. Nine provinces have handled twelve public interest litigation cases involving animal interests since 2018.

Take the protection of dogs as an example. In Professor Hairen He's opinion, almost all local people's congresses or governments with legislative power promulgated more or less rules and regulations on dog management in China. The management of a dog involves some administrative agencies including public safety agency, animal husbandry and veterinary administration, administration of industry and commerce, health management agency, financial management agency, price management agency, urban management administration. Accompanying the managements by different agencies, multiple legal relationships, including administrative legal relations, civil legal relations, criminal legal relations and social legal relations, could occur. It may concern the protection of public interest about the environment, the legitimate rights and interests of consumers, the safety of food and pharmaceuticals, state-owned property, and the transfer of state owned land use rights in detail.

Besides public interest litigation, there are some other ways to protect animals. Professor Lihong Gao from the Zhongnan University of Economics and Law, China, introduced the laboratory animal welfare protection space and its litigation methods in China's existing laws. China, from national to local level, has established a legal system for laboratory animal welfare. That includes the standard system, government management systems, quality inspection systems, statistical reporting systems, hierarchical management systems, licensing systems, and certification systems. In the existing judicial practice, many lawsuits have been filed in accordance with the contract law, tort law and related welfare regulations of laboratory animals, and the causes of action could be "the laboratory animal environment and facilities below standards", "the breeding environment below standards" and "the identification criteria of the experiment below standards". In addition, some expandable litigation path may be taken in the future. For example, where the welfare of laboratory animals is involved in the patent examination, the patent right cannot be granted in accordance with the Patent Law if there is a violation of social morality in the course of the experiment. If there is any violation of the protection norms of laboratory animals in scientific research activities, it can be considered as scientific research misconduct in accordance with Measures for Handling Misconduct in Scientific Research in the Implementation of National Science and Technology Plan (Trial Implementation).

Actually, Mr. Xiang An, a Chinese lawyer from Beijing Dexiang Law Firm, also stressed that the view that there is no animal welfare in China is wrong. There are at least four regulations in China that clearly provide the animal welfare. In addition, he shared two successful cases in the field of companion animal protection and in the field of wildlife conservation. One is that he used the Animal Epidemic Prevention Law and the Food Safety Law to ban cats meat and dogs meat from entering the market. The other is that he successfully prevented a company that used live bears to take bile to make a profit from listing according to the Advertising Law.

Lack of specific animals protection law and some shortcomings among existing act also exist outside China's jurisdiction. Professor Joyce Tischler, Center for Animal Law Studies at Lewis \& Clark Law School, USA, introduced the situation in the United States. Without being protected by federal animal welfare laws and state anti-abuse laws, lawyers have successfully relied on the Unfair Competition Law, the False Advertising Law, the Federal Resource Conservation and Recovery Act., the Federal Clean Water Act., Consumers Legal Remedies Act. and Racketeer Influenced and Corrupt Organizations Act. to protect companion animals and farmed animals.

As an example of the limitations of anti-cruelty legislation, there are some weaknesses among the animals protection act in South Africa. Mr. Tony Gerrans, Executive Director of Humane Society International-Africa, introduced how to use existing laws to better protect animals in South Africa. Not only did they just use the constitutional environmental rights to solve some of the predicaments of wildlife protection, but they also indirectly improved the circumstances of animals through some other branches of law such as companies law, investment law, and consumers protection law.

In addition to the litigation approach, Mr. Chris Green from Harvard Law School, USA, provided an alternative channel. What he focused on was the power of public opinion. He raised 5 strategies in detail, including being more vocal than legislative opponents, using the language $\&$ tactics of those in power, using non-traditional venues as levers, targeting corporate pressure points for consumer sentiment, and creating alternative products to compete in the marketplace.

The second topic of the forum was animal law education. The education of animal law in China has just begun, and listening to and learning extraterritorial experience will be benefit its development. Lewis \& Clark Law School, Harvard Law School, and Hong Kong University Law School introduced their history 
and experiences of animal law education.

The final part of the forum was a competition for the statement of case-handling strategy by 6 Chinese university student teams who stood out from the 17 teams in the previous games. 